Nordisk Tidsskrift for Kriminalvidenskab 2007

\title{
Det XIV Nordiska Kriminalistmötet
}

\section{AV ORDFÖRANDE I SVENSKA KRIMINALISTFÖRENINGEN, ANN-MARIE BEGLER}

I slutet av augusti 2007 anordnades det Nordiska kriminalistmötet i Stockholm. Det var nummer XIV i ordningen. Det var samtidigt ett slags 70 -årsjubileum. Det är nämligen så att det första nordiska mötet lär ha ägt rum i stort sett exakt 70 år tidigare - 20 augusti 1937 i Helsingfors. Det andra mötet ägde rum tio år senare och därefter har mötena genomförts regelbundet men med något kortare mellanrum.

Norge var först ut med att bilda en Kriminalistförening. Det skedde redan 1892. Därefter bildades de olika föreningarna och på 30-talet var alltså det nordiska samarbetet etablerat.

Att den internationella arenan har förändrats oerhört mycket sedan dess behöver knappast sägas. Men även på betydligt kortare sikt har förändringarna varit omfattande och omvälvande. Det internationella samarbetet kan inte alls liknas med hur det såg ut för bara tio eller femton år sedan. Denna förändring gör naturligtvis att vi funderar över det nordiska samarbetet och vikten av det diskuteras. Är det lika viktigt nu som det var tidigare? Fortsätter vi att samarbete bara för att vi alltid har gjort det?

Min uppfattning är att EU-medlemskapet för flera av de nordiska länderna och utvidgningen av EU stärker behovet av ett nordiskt samarbete. Det är minst lika viktigt nu som för sjuttio år sedan. Det som var uppenbart på detta nordiska kriminalistmöte, liksom de tidigare mötena, är likheterna mellan de nordiska länderna både avseende kriminalpolitik och brottslighet. Dessa likheter gör att det är såväl viktigt som intressant att jämföra hur brottsligheten utvecklas och vad olika insatser mot brottsligheten leder till. Och dessa jämförelser behövs för att kunna utveckla kunskaperna och även åtgärderna mot brott och brottslighet. Ett konkret bevis för att det nordiska samarbetet uppfattas som viktig är att det är lätt att få fram talare med hög kompetens från alla nordiska länder och att det på de olika seminarierna har varit fruktbara diskussioner.

Kriminalistmötena är också ett av de få forum där anställda inom rättsväsendet kan möta och diskutera viktiga kriminalpolitiska frågor med forskare och andra representanter från den akademiska världen. Dessa möten mellan olika yrkesgrupper och olika länder gör att det nordiska mötet är ett möte att värna om i framtiden. Vi ser redan fram emot nästa möte som skall hållas i Danmark om tre år. 


\section{PROGRAM FÖR KRIMINALISTMÖTET I STOCKHOLM} 23-25 AUGUSTI 2007

\section{Torsdagen den 23 augusti}

13.00-13.30 Inledningsanförande av justitieminister Beatrice Ask.

13.30-14.30 Plenum. Den ökande rättsliga internationaliseringen

- Norden ett alternativ?

Fredrik Wersäll, Sverige

Gustaf Möller, Finland

15.00-17.00 Plenum. Mänskliga rättigheter. Europakonventionens betydelse inom straffrätten och Norden. Kränkande uttalanden och yt trandefriheter - vad är brottsligt att säga?

Eva Jagander, Sverige

Ragna Aarli, Norge

Vagn Greve, Danmark

Björg Thorarensen, Island

18.00- Mottagning

\section{Fredagen den 24 augusti}

9.30-16.30 Seminarier:

1. Aktuell straffrättsutveckling inom EU. Harmonisering och öm sesidigt erkännande.

Indledare: Dan Frände, Finland

Kommentar: Maria Kelt, Sverige

2. Kunskapsbaserad kriminalvårdspolitik.

Inledare: Britta Kyvsgaard, Danmark

Kommentar: Birgitta Göransson, Sverige

3. Ekonomisk och organiserad brottslighet. Korruption.

Inledare: Lars Korsell, Sverige

Kommentar: Anne Mette Dyrnes, Norge

4. Terroristbekämpning. Sanktionssystemet inom FN och EU.

Inledare: Iain Cameron, Sverige

Kommentar: Fri diskussion

5. Kunskapsbaserad kriminalpolitik.

Inledare: Agneta Bäcklund, Sverige

Kommentar: Jesper Ryberg, Danmark

6. Brottsoffrens ställning

Inledare: Aina Mee Ertzeid, Norge

Kommentar: Henrik Tham, Sverige 
7. Hot mot vittnen och målsägande. Går det att upprätthålla rättvisan?

Kommentar: Johanna Niemi-Kiesiläinen, Finland

8. Lägre straff för medverkan i rättegången - plea bargaining

Inledare: Harald Strand, Norge

Kommentar: Petter Asp, Sverige

9. Psykisk störda lagöverträdare. Ansvarsfrågan och åtgärder.

Inledare: Gorm Gabrielsen, Danmark

10. Straffnivåer i de nordiske länderna jämfört med övriga länder i Europa.

Inledare: Tapio Lappi-Seppälä, Finland

Kommentar: Ulla Bondeson, Danmark

11. Vad gör vi med våra unga lagöverträdare?

Inledare: Hrefna Fridriksdottir, Island

Kommentar: Stina Holmberg, Sverige

12. Är skulden evig? (Preskription)

Inledare: Elina Pirjatanniemi, Finland

Kommentar: Petra Lundh, Sverige

Aften Festmiddag i Restaurang Atrium, Nationalmuseum

\section{Lördagen den 25 augusti}

9.30-13.00 Paneldebatt: Likhet inför lagen.

Ilkka Taipale, Finland

Peter Garde, Danmark

Robert Spano, Island

Ragnhild Hennum, Norge 